\title{
Możliwości występowania gazu zamkniętego w piaskowcach środkowego kambru zachodniej części obniżenia bałtyckiego (wyniesienie Leby) - wstępna analiza na podstawie danych petrofizycznych i geofizyki otworowej
}

\author{
Teresa Adamczak-Biały ${ }^{1}$, Jolanta Pacześna ${ }^{1}$
}
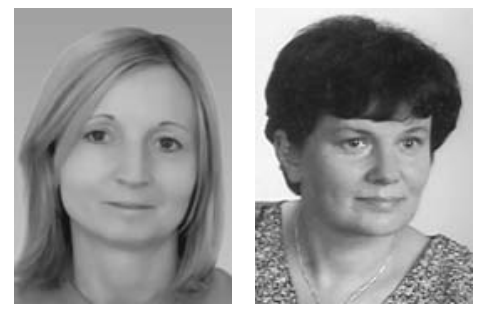

T. Adamczak-Biały J. Pacześna

Prospects of tight gas occurrence in the Middle Cambrian sandstones in the western part of the Baltic Depression (Leba Elevation) - introductory analysis based on petrophysical and well logging data. Prz. Geol., 68: 701-709; doi: 10.7306/2020.28

A b s tra c t. The main purpose of this article is an approximation of petrophysical parameters in selected borehole sections in the Eeba Elevation. The parameters are among the most important factors affecting the possibility of unconventional gas accumulation. The other factors explaining the possibility of tight gas accumulations in the Middle Cambrian sandstones of the Eeba Elevation are hydrocarbon shows in cores and drilling mud and the presence of conventional hydrocarbon fields. The potential hydrocarbon resources are related to the Dębki and Biatogóra Formations. They are composed of fine-grained sandstones. The thickness of the Dębki Formation ranges up to $100 \mathrm{~m}$. The tickness of the Białogóra Formation does not exceed $10 \mathrm{~m}$. The analysis of petrophysical parameters of these formations indicates that their tight gas saturation has a layered character. The Dębki Formation shows a better potential for tight gas accumulation.

Keywords: tight gas, Middle Cambrian sandstones, Dębki Formation, Białogóra Formation, Łeba Elevation, petrophysical parameters

Wyniesienie Łeby (blok B - sensu Pokorski, Modliński, 2007) charakteryzuje się blokową strukturą tektoniczną, na którą składa się wiele mniejszych elementów rozdzielonych uskokami. Jest ono zlokalizowane w środkowej strefie zachodniej części obniżenia bałtyckiego (ryc. 1) i stanowi północny, krańcowy fragment kambryjskiej prowincji ropogazonośnej w polskiej części platformy wschodnioeuropejskiej (Górecki, 2006, 2011). Na obszarze tym w utworach środkowego kambru ( miaolingu), obecnych zarówno na lądzie, jak i na morzu w polskiej strefie ekonomicznej Bałtyku, zostały udokumentowane i są eksploatowane złoża ropy naftowej, gazu ziemnego i kondensatu ropno-gazowego.

W kambryjskim systemie naftowym obniżenia bałtyckiego występuje odbiegająca od standardowej relacja przestrzenna jego poszczególnych elementów. Skały zbiornikowe, którymi są zwięzłe piaskowce środkowego kambru, zalegają poniżej skał macierzystych. Skałę macierzystą i jednocześnie uszczelniającą - zarówno w skali regionalnej, jak i lokalnej - stanowią bogate w substancję organiczną iłowce furongu (górnego kambru), ordowiku i syluru. Niestandardowy układ elementów systemu naftowego w dużej mierze jest spowodowany skomplikowanym planem strukturalnym obniżenia bałtyckiego, głównie synwaryscyjskim, w mniejszym zakresie mezozoiczno-kenozoicznym, i obecnością gęstej sieci uskoków (Dadlez, 1993), stanowiących ścieżki migracji węglowodorów. Nadległa pozycja skały macierzystej i uszczelniającej wymuszała migrację węglowodorów do zalegających niżej środkowokambryjskich skał zbiornikowych. Prawdopodobnie migracja ta była spowodowana równoczasowym wystąpieniem procesów ekspulsji węglowodorów, ich migracji i zdarzeń tektonicznych na wyniesieniu Łeby. Biorąc pod uwagę blokową budowę tego wyniesienia, a także do dziś jednoznacznie nieokreślony - wczesnokarboński lub mezozoiczno-kenozoiczny - czas ekspulsji i migracji węglowodorów (Poprawa, Grotek, 2005; Kosakowski i in., 2010; Kosakowski i in., 2016), można postawić hipotezę o okresowym wypiętrzeniu (w trakcie lub po ekspulsji) niektórych bloków z piaskowcami środkowokambryjskimi. Wypiętrzenie to umożliwiło migrację węglowodorów $\mathrm{z}$ utworów górnego kambru do niżej zalegających skał zbiornikowych środkowego kambru wzdłuż uskoków obcinających bloki tektoniczne. Przedstawiona hipoteza wyjaśnia również rozproszone, typu patches, występowanie nasyceń węglowodorami piaskowców środkowego kambru.

Obecność konwencjonalnych złóż węglowodorów wskazuje na prawdopodobieństwo występowania ich niekonwencjonalnych odpowiedników. Należą do nich potencjalne akumulacje gazu zamkniętego (tight gas). Analiza możliwości występowania akumulacji złożowych gazu zamkniętego w utworach kambru środkowego wyniesienia Łeby była dotychczas dokonywana w bardzo wąskim zakresie na podstawie materiałów wiertniczych gromadzonych od wielu lat w archiwach rdzeni Państwowego Instytutu Geologicznego - Państwowego Instytutu Badawczego (PIG-PIB) oraz firm Lotos Petrobaltic S.A. i Polskie Górnictwo Naftowe i Gazownictwo S.A.

W ostatnim dziesięcioleciu w zachodniej części obniżenia bałtyckiego firmy naftowe odwierciły nowe otwory poszukiwawczo-rozpoznawcze w formacjach łupkowych niższego paleozoiku. W wielu miejscach nawiercono lub przewiercono stropową część utworów środkowego kambru, dostarczając zbioru nowych danych, które umożliwiły dokonanie wstępnej analizy potencjału akumulacji gazu zamkniętego w utworach środkowego kambru wyniesienia Łeby. Głównym celem niniejszego artykułu jest określenie petrofizycznych parametrów skał w wybranych profilach

Państwowy Instytut Geologiczny - Państwowy Instytut Badawczy, ul. Rakowiecka 4, 00-975 Warszawa; teresa.adamczak@pgi.gov.pl 
otworów wiertniczych zlokalizowanych na wyniesieniu Łeby i dokonanie na ich podstawie wstępnej analizy możliwości występowania niekonwencjonalnych złóż gazu zamkniętego w tej strukturze.

\section{GEOLOGICZNE UWARUNKOWANIA \\ WYSTEPOWANIA GAZU ZAMKNIETEGO W UTWORACH OBNIŻENIA BALTYCKIEGO}

We wczesnym paleozoiku obniżenie bałtyckie było basenem perykratonicznym, który stanowił rozległą, regionalną nieckę $\mathrm{w}$ osadowej pokrywie zachodniego, pasywnego brzegu Baltiki (Poprawa, Pacześna, 2002; Pacześna, Poprawa, 2005). Ropogazonośne utwory środkowego kambru należą do kambryjskiej sekwencji osadowego, dolnopaleozoicznego wypełnienia tego basenu. Obok nich basen ten wypełniają klastyczne utwory wyższego ediakaru, dolnego kambru oraz klastyczno-węglanowe osady furongu (górnego kambru), ordowiku i syluru. Skały osadowe zalegają na proterozoicznym podłożu krystalicznym (Ryka, 1990). Na utworach niższego paleozoiku, z niewielką niezgodnością kątową, spoczywają utwory dewonu.
Występowanie złóż ropy naftowej, gazu ziemnego i kondensatu w zachodniej części obniżenia bałtyckiego w znacznym stopniu jest uwarunkowane planem strukturalno-tektonicznym, który ukształtował się w trakcie trzech etapów deformacji tektonicznych: synkaledońskich po sylurze, synwaryscyjskich przed permem i synalpejskich we wczesnym mezozoiku i późnym kenozoiku (Dadlez, 1993). W wyniku tych przekształceń część zachodnia i środkowa obniżenia bałtyckiego oraz bezpośrednio przylegające do niego obszary morskie polskiej, ekonomicznej strefy Bałtyku dzielą się na kilka bloków tektonicznych. Są to bloki: A - Słupska, B - Łeby, C - Gdańska, Żarnowca i Rozewia oraz D - blok Kurlandii (ryc. 1), oddzielone od siebie regionalnymi strefami dyslokacyjnymi (Pokorski, Modliński, 2007). Udokumentowane konwencjonalne złoża węglowodorów występują w pułapkach strukturalno-litologicznych w bloku B Łeby - w wyniesionych strukturach obciętych lokalnymi strefami uskokowymi (Karczewska, Żurawski, 1998; Królicka, 1998). Obok konwencjonalnych złóż węglowodorów inną przesłanką, wskazującą na możliwość występowania nagromadzeń gazu zamkniętego w utworach środkowego kambru wyniesienia

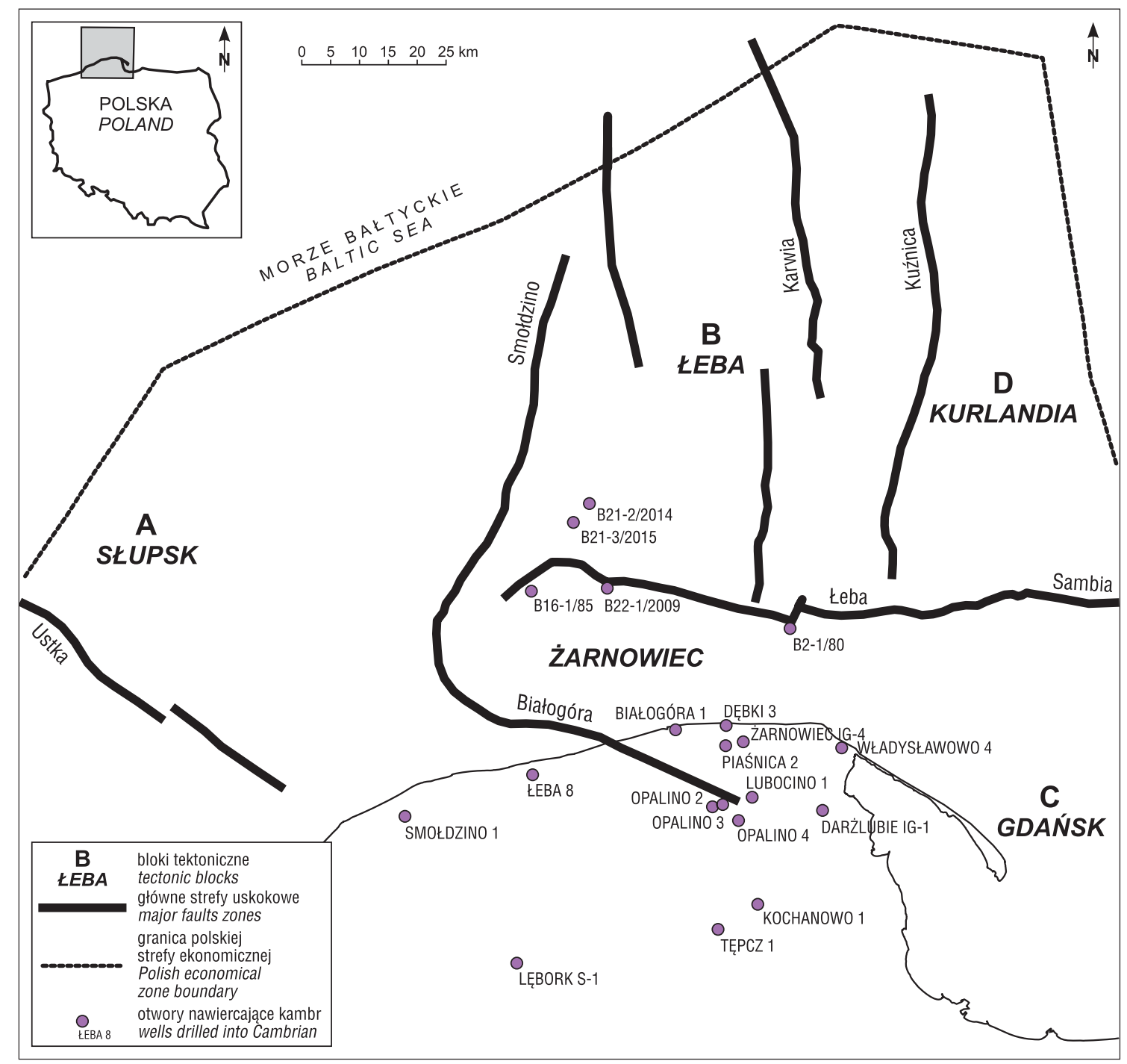

Ryc. 1. Schematyczna mapa głównych bloków tektonicznych w zachodniej części obniżenia bałtyckiego (według Pokorskiego, Modlińskiego, 2007) z lokalizacją wybranych otworów wiertniczych, w których nawiercono utwory kambru Fig. 1. Sketch-map showing the main tectonic blocks in the western part of the Baltic Depression (after Pokorski, Modliński, 2007) with location of selected boreholes that drilled into the Cambrian deposits 
Łeby, jest obecność licznych objawów węglowodorów w płuczce, do których należy obecność gazu, przypływy gazu palnego i przypływy solanki ze śladami gazu palnego. Do objawów stwierdzanych w rdzeniu należy wydzielanie się gazu z mikroszczelin, pojedyncze pęcherzyki gazu i punktowe odgazowania w spękaniach skały.

$\mathrm{Na}$ wyniesieniu Łeby ropogazonośne utwory piaskowcowe występują $\mathrm{w}$ górnych częściach profilu środkowego kambru, w poziomach Paradoxides paradoxissimus i Paradoxides forchhammeri (Lendzion, 1983; Pacześna, 2011), które obejmują odpowiednio formację dębkowską i formację białogórską (Jaworowski, 2011; Pacześna, 2011).

Formację dębkowską reprezentują piaskowce sporadycznie przewarstwione heterolitami piaskowcowo-mułowcowo-iłowcowymi lub piaskowce $\mathrm{z}$ bardzo cienkimi warstwami wapieni. Większość profilu formacji zajmują zwięzłe, kwarcowe piaskowce drobnoziarniste, zdeponowane w przybrzeżnej strefie regresywnego zbiornika morskiego (Jaworowski, 2000; Pacześna, 2012). Tworzą one we wszystkich profilach wiertniczych wyniesienia Łeby charakterystyczny kompleks skalny o miąższości nieprzekra-

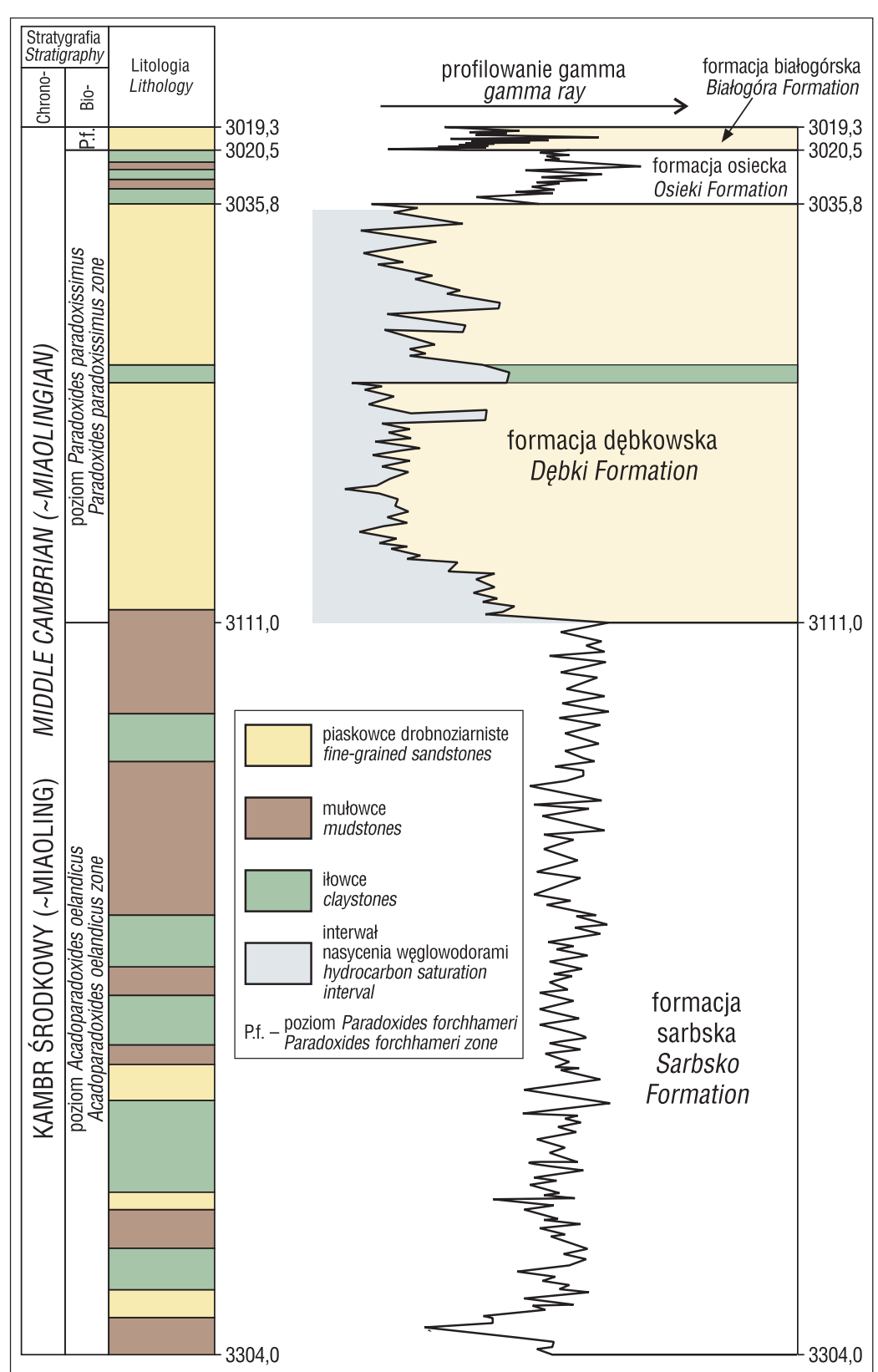

czającej $100 \mathrm{~m}$ (ryc. 2). Skały zbiornikowe to piaskowce kwarcowe o spoiwie krzemionkowym i węglanowym. Reprezentuja one porowo-szczelinowy, szczelinowy lub porowy typ skał zbiornikowych (Karczewska, Żurawski, 1998). Ropogazonośne piaskowce środkowokambryjskie są od stropu ekranowane iłowcowymi i mułowcowymi utworami górnego kambru (furongu), ordowiku i syluru lub lokalnie na skutek zaniku właściwości zbiornikowych kolektora.

Formacja białogórska składa się z jasnoszarych, zwięzłych piaskowców drobno- $i$ średnioziarnistych o spoiwie węglanowym, z licznymi ziarnami glaukonitu i drobnymi konkrecjami fosforytowymi. W piaskowcach tych występują nieliczne, nieregularne przewarstwienia czarnych iłowców i mułowców. Zasięg formacji jest ograniczony regionalnie. Miąższość formacji białogórskiej jest niewielka i waha się od 2 do $10 \mathrm{~m}$ (ryc. 2). Jej obecność stwierdzono tylko w morskiej przylądowej części wyniesienia Łeby i wysuniętej najbardziej na północ - lądowej. Ku zachodniej krawędzi platformy wschodnioeuropejskiej, w kierunku południowym i południowo-zachodnim, w strefie lądowej wyniesienia Łeby formacja białogórska zanika na skutek usunięcia przez erozję.

\section{METODYKA}

Analizie poddano wyniki laboratoryjnych pomiarów petrofizycznych parametrów próbek skał kambru, które pobrano z rdzeni 21 otworów wiertniczych zlokalizowanych w zachodniej części obniżenia bałtyckiego (ryc. 1), m.in. porowatości całkowitej, porowatości efektywnej i przepuszczalności poziomej. Przestudiowano także interpretację wyników badań geofizycznych wykonanych w profilach 14 otworów wiertniczych spośród 21, w których nawiercono utwory kambru. Należy podkreślić, że większość otworów wykonanych po $2010 \mathrm{r}$. była dedykowana poszukiwaniom gazu ziemnego $\mathrm{w}$ formacjach łupkowych (shale gas). Utwory

\section{$\leftarrow$}

Ryc. 2. Reprezentatywny dla południowej części bloku B wyniesienia Łeby litologiczno-stratygraficzny profil sukcesji środkowokambryjskiej w otworze wiertniczym Darżlubie IG-1, pokazujący interwał nasycenia węglowodorami (wg Pacześnej, 2012, zmieniony); biostratygrafia wg Lendzion (1983), litostratygrafia wg Jaworowskiego, 2011

Fig. 2. Lithologic-stratigraphical section of the Middle Cambrian succession of the Darżlubie IG-1 borehole, representative for the southern part of Block B in the Łeba Elevation, showing a hydrocarbon saturation interval (after Pacześna, 2012, changed); biostratigraphy after Lendzion (1983), lithostratigraphy after Jaworowski (2011) 
kambru były w nich zwykle traktowane marginalnie nawiercano i badano je w niewielkim tylko zakresie - dlatego też dysponowano ograniczoną liczbą danych umożliwiających wyczerpującą analizę utworów kambryjskich i szczegółową ocenę ich potencjału węglowodorowego.

Do ustalenia kryteriów złożowych, jakie powinny spełniać osadowe formacje skalne, aby można było uznać je za perspektywiczne pod względem występowania złóż gazu zamkniętego, wykorzystano wyniki badań kratonu wschodnioeuropejskiego (Wójcicki i in., 2014) oraz innych basenów naftowych (np. Koehrer i in., 2014; Lee, 2013). Przyjęto następujące kryteria ilościowe:

$\square$ słaba przepuszczalność - poniżej $0,1 \mathrm{mD}$, jednak nie zerowa;

$\square$ obniżona porowatość całkowita, ale wciąż zachowana, nie mniejsza niż 3\%;

$\square$ porowatość efektywna nie mniejsza niż 2\%;

$\square$ zailenie nie większe niż 55\%;

$\square$ nasycenie wodą złożową nie większe niż $60 \%$;

$\square$ ciśnienie złożowe wyższe od ciśnienia hydrostatycznego.

Oprócz tych kryteriów istotny jest również stopień konsolidacji skał rozpatrywanego kompleksu perspektywicznego, a także jego: homogeniczność, duża kubatura i znaczna regionalna rozciagłość; odpowiednia głębokość pogrążenia; obecność w kompleksie lub w jego pobliżu odpowiednio dojrzałej skały macierzystej; usytuowanie w szybko pogrzebanym i podgrzanym, a następnie wypiętrzonym basenie naftowym; występowanie objawów gazu oraz konwencjonalnych złóż gazu w tym samym basenie (Podhalańska i in., 2018).

Biorąc pod uwagę wymienione kryteria złożowe do dalszej analizy wybrano utwory formacji kambru środkowego, tj. formacji białogórskiej lub też dębkowskiej, nawiercone w czterech otworach wiertniczych: Lębork S-1, Darżlubie IG-1, B16-1 i B21-2 (ryc. 1). Próbę wstępnego scharakteryzowania potencjału tych formacji do akumulacji gazu ziemnego podjęto, korzystając $\mathrm{z}$ wyników badań laboratoryjnych (przepuszczalności oraz porowatości całkowitej i efektywnej) oraz interpretacji pomiarów geofizyki wiertniczej (porowatości całkowitej i efektywnej oraz zailenia). Zakresy wartości tych parametrów petrofizycznych, z podaniem źródła pochodzenia danych, wartości wyliczonej mediany oraz średnich, zaprezentowano w tab. 1-7. Ponieważ porowatość i zailenie opisywanych formacji skalnych charakteryzują się normalnym rozkładem zmiennych, policzono średnie arytmetyczne tych parametrów. Ze względu na to, że dla przepuszczalności jest właściwy rozkład logarytmiczno-normalny, obliczono średnie geometryczne tego parametru.

Na koniec trzeba zwrócić uwagę na kwestię różnic w metodyce i czasie pomiarów parametrów petrofizycznych wykorzystanych do oceny możliwości występowania gazu zamkniętego w piaskowcach środkowego kambru zachodniej części obniżenia bałtyckiego (wyniesienie Łeby) w profilu otworu Darżlubie IG-1. Otwór ten został odwiercony w 1973 r. i analizy laboratoryjne próbek rdzenia wiertniczego pobranych z tego otworu zostały wykonane z użyciem ówcześnie dostępnej aparatury i metodyki. Współcześnie laboratoryjne badania rdzenia z otworu Darżlubie IG-1 zostały zrealizowane za pomocą nowoczesnej aparatury i metodyki pomiarowej (INiG-PIB, 2018). Pomiary przepuszczalności skał zrealizowano analizując przepływ w stanie nieustalonym metodą spadku pulsu ciśnienia (pulse decay) za pomocą urządzenia PDP-250 Pulse Decay firmy CoreLab®. Metoda pulse decay jest przeznaczona do badania skał o ultraniskiej przepuszczalności (rzędu $\mu \mathrm{D}$ lub nD).

Laboratoryjne pomiary przepuszczalności skał są wykonywane głównie za pomocą analizy przepływu w stanie ustalonym (tj. przepływu, w którym ciśnienie w każdym punkcie analizowanego ośrodka nie zmienia się w czasie). W trakcie badań prowadzonych w latach 2016-2018, dzięki zastosowaniu nowoczesnych metod badawczych uzyskano bardziej precyzyjne wyniki pomiarów parametrów petrofizycznych skał niż te, które otrzymano w latach 70., gdy otwór Darżlubie IG-1 został odwiercony i po raz pierwszy przebadany.

\section{OCENA FORMACJI KAMBRU ŚRODKOWEGO POD WZGLEDEM PERSPEKTYW WYSTEPOWANIA ZLÓŻ GAZU ZAMKNIĘTEGO}

W otworze Lębork S-1 (odwierconym w 2011 r.) w utworach środkowego kambru wydzielono interwał formacji dębkowskiej o miąższości 19 m (3552,5-3571,5 m). Porowatość całkowita piaskowców tej formacji, określona na podstawie badań geofizycznych (Wróblewski, 2012), mieści się w przedziale 1,7-17\% (mediana 4\%, średnia arytmetyczna 5,6\%), porowatość efektywna osiaga do 12,3\% (mediana 1,8\%, średnia arytmetyczna 2,5\%), a zailenie mieści się w przedziale 9-62\% (mediana 26\%, średnia arytmetyczna 28\%). Przepuszczalność 4 próbek rdzenia, pomierzona laboratoryjnie (laboratorium TerraTek, Schlumberger Company, Stany Zjednoczone), wynosi od 0,0002 do $0,0004 \mathrm{mD}$ (Wróblewski, 2012). Biorąc pod uwagę kryteria przyjęte dla skał perspektywicznych pod względem akumulacji gazu zamkniętego, parametry petrofizyczne formacji dębkowskiej (tab. 1), określone w profilu otworu Lębork S-1, są obiecujące.

W otworze B16-1 (z 1985 r.) kompleks formacji dębkowskiej występuje w interwale 1900,6-1975,0 m. Sześć próbek skał tej formacji, pobranych z rdzenia wiertniczego, poddano analizom laboratoryjnym (INiG-PIB, 2018). Porowatość całkowita piaskowców tego kompleksu, określona metodą rezonansu magnetycznego, mieści się w przedziale od 1,0 do 9,3\% (mediana 4,5\%, średnia arytmetyczna 4,6\%). Przepuszczalność 3 próbek wyniosła $0,00004 \mathrm{mD} ; 0,013 \mathrm{mD}$ i $0,059 \mathrm{mD}$ (tab. 2). Porowatość efektywna formacji dębkowskiej, określona na podstawie interpretacji pomiarów geofizyki wiertniczej (INiG-PIB, 2018), osiaga do 9\% (mediana wynosi 4,3\%, średnia arytmetyczna 2,5\%). Zailenie tej formacji mieści się w zakresie od 4,2 do 58,6\% (mediana 38,9\%, średnia arytmetyczna $35,7 \%)$.

Utwory formacji białogórskiej są obecne w profilu otworu B16-1 na głębokości 1871,3-1879,3 m. Porowatość efektywna i zailenie skał tej formacji, określone na podstawie badań geofizycznych (INiG-PIB, 2018; tab. 3), wynoszą odpowiednio: do $6,2 \%$ (mediana 4,3\%, średnia arytmetyczna $3,8 \%$ ) oraz do $16,6 \%$ (mediana $10,2 \%$, średnia arytmetyczna 9,1\%).

Wyniki pomiarów porowatości, przepuszczalności i zailenia piaskowcowych formacji kambru środkowego w otworze B16-1 (tab. 2 i 3) wskazują na potencjał tych skał do akumulacji niekonwencjonalnych złóż gazu typu tight. 
Tab. 1. Parametry petrofizyczne formacji dębkowskiej w otworze Lębork S-1 (wg Wróblewskiego, 2012)

Tabble 1. Petrophysical parameters of the Dębki Formation in the Lębork S-1 borehole (after Wróblewski, 2012)

\begin{tabular}{|l|c|c|c|c|c|}
\hline \multicolumn{1}{|c|}{$\begin{array}{c}\text { Parametry petrofizyczne } \\
\text { Petrophysical parameters }\end{array}$} & \multicolumn{3}{c|}{$\begin{array}{c}\text { Formacja dębkowska } \\
\text { Dębi Formation }\end{array}$} & $\begin{array}{c}\text { Mediana } \\
\text { Median }\end{array}$ & $\begin{array}{c}\text { Średnia } \\
\text { Average }\end{array}$ \\
\cline { 2 - 6 } & $\begin{array}{c}\text { Liczba próbek } \\
\text { Number } \\
\text { of samples }\end{array}$ & Min. & Max. & 3,96 & 5,6 \\
\hline $\begin{array}{l}\text { Porowatość całkowita [\%] - interpretacja geofizyczna } \\
\text { Total porosity [\%] - geophysical interpretation }\end{array}$ & - & 1,74 & 17 & 3,19 & 3,48 \\
\hline $\begin{array}{l}\text { Porowatość całkowita [\%] - pomiary laboratoryjne } \\
\text { Total porosity [\%] - laboratory measurements }\end{array}$ & 4 & 2,32 & 5,21 & \multirow{2}{*}{1,75} & 2,49 \\
\hline $\begin{array}{l}\text { Porowatość efektywna [\%] - interpretacja geofizyczna } \\
\text { Effective porosity [\%] - geophysical interpretation }\end{array}$ & - & 0,01 & 12,25 & 3,18 & 3,03 \\
\hline $\begin{array}{l}\text { Porowatość efektywna [\%] - pomiary laboratoryjne } \\
\text { Effective porosity [\%] - laboratory measurements }\end{array}$ & 4 & 2,24 & 3,52 & \multirow{2}{*}{0,00025} & 0,00026 \\
\hline $\begin{array}{l}\text { Przepuszczalność [mD] - pomiary laboratoryjne } \\
\text { Permeability [mD] - laboratory measurements }\end{array}$ & 4 & 0,0002 & 0,0004 & 26 \\
\hline $\begin{array}{l}\text { Zailenie [\%] - interpretacja geofizyczna } \\
\text { Shaliness [\%] - geophysical interpretation }\end{array}$ & - & 8,8 & 61,6 & 26 \\
\hline
\end{tabular}

Tab. 2. Parametry petrofizyczne formacji dębkowskiej w otworze B16-1 (INiG-PIB, 2018)

Tabble 2. Petrophysical parameters of the Dębki Formation in the B16-1 borehole (INiG-PIB, 2018)

\begin{tabular}{|c|c|c|c|c|c|}
\hline \multirow[b]{2}{*}{$\begin{array}{l}\text { Parametry petrofizyczne } \\
\text { Petrophysical parameters }\end{array}$} & \multicolumn{5}{|c|}{$\begin{array}{l}\text { Formacja dębkowska } \\
\text { Dębki Formation }\end{array}$} \\
\hline & $\begin{array}{c}\text { Liczba } \\
\text { próbek } \\
\text { Number } \\
\text { of samples }\end{array}$ & Min. & Max. & $\begin{array}{l}\text { Mediana } \\
\text { Median }\end{array}$ & $\begin{array}{l}\text { Średnia } \\
\text { Average }\end{array}$ \\
\hline $\begin{array}{l}\text { Porowatość całkowita }[\%] \text { - pomiary laboratoryjne } \\
\text { Total porosity [\%] - laboratory measurements }\end{array}$ & 6 & 1,21 & 5,47 & 3,92 & 3,62 \\
\hline $\begin{array}{l}\text { Porowatość całkowita [\%] - pomiary laboratoryjne (rezonans magnetyczny) } \\
\text { Total porosity[\%] - laboratory measurements (nuclear magnetic resonance) }\end{array}$ & 6 & 1,04 & 9,33 & 4,53 & 4,59 \\
\hline $\begin{array}{l}\text { Porowatość efektywna [\%] - interpretacja geofizyczna } \\
\text { Effective porosity [\%] - geophysical interpretation }\end{array}$ & - & 0 & 9,1 & 4,3 & 2,5 \\
\hline $\begin{array}{l}\text { Porowatość efektywna [\%] - pomiary laboratoryjne (rezonans magnetyczny) } \\
\text { Effective porosity [\%] - laboratory measurements (nuclear magnetic resonance) }\end{array}$ & 6 & 0,24 & 5,26 & 2,79 & 2,82 \\
\hline $\begin{array}{l}\text { Przepuszczalność }[\mathrm{mD}] \text { - pomiary laboratoryjne } \\
\text { Permeability }[\mathrm{mD}] \text { - laboratory measurements }\end{array}$ & 3 & 0,00004 & 0,059 & 0,014 & 0,003 \\
\hline $\begin{array}{l}\text { Zailenie }[\%] \text { - interpretacja geofizyczna } \\
\text { Shaliness [\%] - geophysical interpretation }\end{array}$ & - & 4,24 & 58,6 & 38,9 & 35,7 \\
\hline
\end{tabular}

Tab. 3. Parametry petrofizyczne formacji białogórskiej w otworze B16-1 (INiG-PIB, 2018)

Tabble 3. Petrophysical parameters of the Białogóra Formation in the B16-1 borehole (INiG-PIB, 2018)

\begin{tabular}{|c|c|c|c|c|c|}
\hline \multirow[b]{2}{*}{$\begin{array}{l}\text { Parametry petrofizyczne } \\
\text { Petrophysical parameters }\end{array}$} & \multicolumn{5}{|c|}{$\begin{array}{l}\text { Formacja bialogórska } \\
\text { Biatogóra Formation }\end{array}$} \\
\hline & $\begin{array}{c}\text { Liczba } \\
\text { próbek } \\
\text { Number } \\
\text { of samples }\end{array}$ & Min. & Max. & $\begin{array}{l}\text { Mediana } \\
\text { Median }\end{array}$ & $\begin{array}{l}\text { Średnia } \\
\text { Average }\end{array}$ \\
\hline $\begin{array}{l}\text { Porowatość całkowita [\%] - pomiary laboratoryjne } \\
\text { Total porosity [\%] - laboratory measurements }\end{array}$ & 1 & 1,56 & 1,56 & 1,56 & 1,56 \\
\hline $\begin{array}{l}\text { Porowatość całkowita [\%]- pomiary laboratoryjne (rezonans magnetyczny) } \\
\text { Total porosity[\%] - laboratory measurements (nuclear magnetic resonance) }\end{array}$ & 1 & 1,37 & 1,37 & 1,37 & 1,37 \\
\hline $\begin{array}{l}\text { Porowatość efektywna [\%]- interpretacja geofizyczna } \\
\text { Effective porosity [\%] - geophysical interpretation }\end{array}$ & - & 0 & 6,20 & 4,30 & 3,83 \\
\hline $\begin{array}{l}\text { Porowatość efektywna [\%] - pomiary laboratoryjne (rezonans magnetyczny) } \\
\text { Effective porosity [\%] - laboratory measurements (nuclear magnetic resonance) }\end{array}$ & 1 & 1,36 & 1,36 & 1,36 & 1,36 \\
\hline $\begin{array}{l}\text { Zailenie [\%] - interpretacja geofizyczna } \\
\text { Shaliness [\%] - geophysical interpretation }\end{array}$ & - & 0,12 & 16,60 & 10,20 & 9,10 \\
\hline
\end{tabular}


W otworze B21-2 (z 2014 r.) formację dębkowską wydzielono w interwale głębokościowym 1802,0-1867,5 m, a białogórską na głębokości 1789,5-1792,5 m. Wyniki analiz 76 próbek piaskowców formacji dębkowskiej, pobranych $\mathrm{z}$ rdzenia tego otworu wiertniczego, wskazują (Kubala i in., 2015; tab. 4), że skały tej formacji charakteryzują się porowatością całkowitą $2-11 \%$ (mediana i średnia arytmetyczna wynoszą 6,5\%). Przepuszczalność próbek tych skał zawiera się w przedziale $0-10 \mathrm{mD}$ (mediana $0,1 \mathrm{mD}$, średnia geometryczna $0,29 \mathrm{mD}$ ).

Parametry petrofizyczne piaskowców formacji białogórskiej, które zostały określone na podstawie laboratoryjnych analiz 7 próbek pobranych $\mathrm{z}$ rdzenia otworu wiertniczego B21-2, oraz wyniki interpretacji pomiarów geofizyki wiertniczej, wykonanych w profilu tego otworu (Kubala i in., 2015; tab. 5) wskazują, że skały tej formacji charakteryzują się porowatością całkowitą i efektywną osiągającą ok. $6,5 \%$, przepuszczalnością od 0 do $0,4 \mathrm{mD}$ i zaileniem od 12 do $79 \%$ (mediana $40 \%$, średnia arytmetyczna $38 \%$ ).

Na podstawie dostępnych wyników pomiarów porowatości, przepuszczalności i zailenia skał formacji dębkowskiej i białogórskiej (tab. 4 i 5) można wnioskować, że obie formacje są perspektywiczne pod względem występowania w nich poziomów nasyconych gazem zamkniętym.

W otworze Darżlubie IG-1 (z 1973 r.) utwory formacji dębkowskiej są obecne w interwale głębokościowym 3035,8-3111,0 m. Analiza parametrów petrofizycznych wskazuje, że porowatość i zailenie tych skał spełniają kryteria przyjęte w celu wytypowania formacji o potencjale do akumulacji gazu zamkniętego (tab. 6; ryc. 3). Porowatość

Tab. 4. Parametry petrofizyczne formacji dębkowskiej w otworze B21-2 (wg Kubali i in., 2015)

Tabble 4. Petrophysical parametres of the Dębki Formation in the B21-2 borehole (after Kubala et al., 2015)

\begin{tabular}{|c|c|c|c|c|c|}
\hline \multirow{2}{*}{$\begin{array}{l}\text { Parametry petrofizyczne } \\
\text { Petrophysical parameters }\end{array}$} & \multicolumn{5}{|c|}{$\begin{array}{l}\text { Formacja dębkowska } \\
\text { Dębki Formation }\end{array}$} \\
\hline & $\begin{array}{l}\text { Liczba próbek } \\
\text { Number } \\
\text { of samples }\end{array}$ & Min. & Max. & $\begin{array}{l}\text { Mediana } \\
\text { Median }\end{array}$ & $\begin{array}{l}\text { Średnia } \\
\text { Average }\end{array}$ \\
\hline $\begin{array}{l}\text { Porowatość całkowita [\%] - interpretacja geofizyczna } \\
\text { Total porosity [\%] - geophysical interpretation }\end{array}$ & - & 0,023 & 10,9 & 1,15 & 2,57 \\
\hline $\begin{array}{l}\text { Porowatość całkowita [\%] - pomiary laboratoryjne } \\
\text { Total porosity [\%] - laboratory measurements }\end{array}$ & 76 & 1,99 & 11,37 & 6,54 & 6,52 \\
\hline $\begin{array}{l}\text { Porowatość efektywna [\%] - interpretacja geofizyczna } \\
\text { Effective porosity [\%] - geophysical interpretation }\end{array}$ & - & 0 & 10,85 & 1,1 & 2,52 \\
\hline $\begin{array}{l}\text { Porowatość efektywna [\%] - pomiary laboratoryjne } \\
\text { Effective porosity [\%] - laboratory measurements }\end{array}$ & 76 & 1,98 & 11,37 & 6,21 & 6,34 \\
\hline $\begin{array}{l}\text { Przepuszczalność }[\mathrm{mD}] \text { - interpretacja geofizyczna } \\
\text { Permeability }[\mathrm{mD}]-\text { geophysical interpretation }\end{array}$ & - & 0 & 3,74 & 0,0004 & 0,014 \\
\hline $\begin{array}{l}\text { Przepuszczalność }[\mathrm{mD}] \text { - pomiary laboratoryjne } \\
\text { Permeability }[\mathrm{mD}] \text { - laboratory measurements }\end{array}$ & 76 & 0 & 10,03 & 0,141 & 0,29 \\
\hline $\begin{array}{l}\text { Zailenie [\%] - interpretacja geofizyczna } \\
\text { Shaliness [\%] - geophysical interpretation }\end{array}$ & - & 1,4 & 91,4 & 23,4 & 27,3 \\
\hline
\end{tabular}

Tab. 5. Parametry petrofizyczne formacji białogórskiej w otworze B21-2 (wg Kubali i in., 2015)

Table 5. Petrophysical parameters of the Białogóra Formation in the B21-2 borehole (after Kubala et al., 2015)

\begin{tabular}{|c|c|c|c|c|c|}
\hline \multirow{2}{*}{$\begin{array}{l}\text { Parametry petrofizyczne } \\
\text { Petrophysical parameters }\end{array}$} & \multicolumn{5}{|c|}{$\begin{array}{l}\text { Formacja białogórska } \\
\text { Bialogóra Formation }\end{array}$} \\
\hline & $\begin{array}{l}\text { Liczba próbek } \\
\text { Number } \\
\text { of samples }\end{array}$ & Min. & Max. & $\begin{array}{l}\text { Mediana } \\
\text { Median }\end{array}$ & $\begin{array}{l}\text { Średnia } \\
\text { Average }\end{array}$ \\
\hline $\begin{array}{l}\text { Porowatość całkowita }[\%] \text { - interpretacja geofizyczna } \\
\text { Total porosity [\%] - geophysical interpretation }\end{array}$ & - & 0,051 & 6,220 & 0,140 & 1,170 \\
\hline $\begin{array}{l}\text { Porowatość całkowita [\%] - pomiary laboratoryjne } \\
\text { Total porosity [\%] - laboratory measurements }\end{array}$ & 7 & 1,760 & 6,680 & 2,280 & 3,110 \\
\hline $\begin{array}{l}\text { Porowatość efektywna [\%] - interpretacja geofizyczna } \\
\text { Effective porosity [\%] - geophysical interpretation }\end{array}$ & - & 0,000 & 6,200 & 0,000 & 1,110 \\
\hline $\begin{array}{l}\text { Porowatość efektywna [\%] - pomiary laboratoryjne } \\
\text { Effective porosity [\%] - laboratory measurements }\end{array}$ & 7 & 1,700 & 6,560 & 2,190 & 3,060 \\
\hline $\begin{array}{l}\text { Przepuszczalność }[\mathrm{mD}] \text { - interpretacja geofizyczna } \\
\text { Permeability }[m D]-\text { geophysical interpretation }\end{array}$ & - & 0,000 & 0,400 & 0,000 & 0,004 \\
\hline $\begin{array}{l}\text { Przepuszczalność }[\mathrm{mD}] \text { - pomiary laboratoryjne } \\
\text { Permeability }[\mathrm{mD}] \text { - laboratory measurements }\end{array}$ & 7 & 0,000 & 0,022 & 0,012 & 0,0140 \\
\hline $\begin{array}{l}\text { Zailenie [\%] - interpretacja geofizyczna } \\
\text { Shaliness [\%] - geophysical interpretation }\end{array}$ & - & 12,700 & 79,300 & 40,000 & 38,000 \\
\hline
\end{tabular}


efektywna, stwierdzona na podstawie interpretacji badań geofizycznych, osiaga do $6,5 \%$ (mediana $\%$, średnia arytmetyczna 2,03\%), a zailenie wynosi od $1,2 \%$ do $65,3 \%$ (mediana 21,6\%, średnia arytmetyczna 25,9\%). Rezultaty laboratoryjnych badań utworów formacji dębkowskiej (64 próbki rdzenia) wskazują, że porowatość efektywna tych skał zawiera się w przedziale $0,2-10,1 \%$ (mediana $2,5 \%$, średnia arytmetyczna 4,0\%), a przepuszczalność mieści się w granicach $0,0-3,6 \mathrm{mD}$ (mediana $0,15 \%$, średnia geometryczna $0,32 \%$; Areń i in., 1974).

Bardziej precyzyjny obraz przepuszczalności utworów formacji dębkowskiej uzyskano podczas badań laborato- ryjnych wykonanych w Instytucie Nafty i Gazu w 2018 r. na potrzeby realizacji projektu PIG-PIB (INiG-PIB, 2018). Na podstawie wyników badań 21 próbek rdzenia stwierdzono, że utwory te mają przepuszczalność od 0,0003 do 0,6 $\mathrm{mD}$ (mediana $0,002 \mathrm{mD}$, średnia geometryczna $0,003 \mathrm{mD}$ ). Porowatość efektywna 21 próbek rdzenia formacji dębkowskiej, pomierzona metodą rezonansu magnetycznego, wynosiła $0,7-5,9 \%$ (mediana $2,5 \%$, średnia arytmetyczna $2,6 \%)$

Wyniki pomiarów porowatości, przepuszczalności i zailenia piaskowcowej formacji dębkowskiej, uzyskane w trakcie badań próbek rdzenia z otworu Darżlubie IG-1

Tab. 6. Parametry petrofizyczne formacji dębkowskiej w otworze Darżlubie IG-1

Table 6. Petrophysical parameters of the Dębki Formation in the Darżlubie IG-1 borehole

\begin{tabular}{|c|c|c|c|c|c|}
\hline \multirow[b]{2}{*}{$\begin{array}{l}\text { Parametry petrofizyczne } \\
\text { Petrophysical parameters }\end{array}$} & \multicolumn{5}{|c|}{$\begin{array}{c}\text { Formacja dębkowska } \\
\text { Dębki Formation }\end{array}$} \\
\hline & $\begin{array}{c}\text { Liczba } \\
\text { próbek } \\
\text { Number } \\
\text { of samples }\end{array}$ & Min. & Max. & $\begin{array}{l}\text { Mediana } \\
\text { Median }\end{array}$ & $\begin{array}{l}\text { Średnia } \\
\text { Average }\end{array}$ \\
\hline $\begin{array}{l}\text { Porowatość całkowita [\%] - pomiary laboratoryjne (rezonans magnetyczny) } \\
\text { Total porosity[\%] - laboratory measurements (nuclear magnetic resonance) } \\
\text { (INiG-PIB, 2018) }\end{array}$ & 21 & 0,680 & 6,03 & 2,460 & 2,670 \\
\hline $\begin{array}{l}\text { Porowatość efektywna [\%] - interpretacja geofizyczna } \\
\text { Effective porosity [\%] - geophysical interpretation } \\
\text { (INiG-PIB, 2018) }\end{array}$ & - & 0,000 & 6,50 & 1,930 & 2,030 \\
\hline $\begin{array}{l}\text { Porowatość efektywna [\%] - pomiary laboratoryjne } \\
\text { Effective porosity [\%] - laboratory measurements } \\
\text { (Areń i in., 1974) }\end{array}$ & 64 & 0,200 & 10,10 & 2,450 & 3,970 \\
\hline $\begin{array}{l}\text { Porowatość efektywna [\%] - pomiary laboratoryjne (rezonans magnetyczny) } \\
\text { Effective porosity [\%] - pomiary laboratoryjne (nuclear magnetic resonance) } \\
\text { (INiG-PIB, 2018) }\end{array}$ & 21 & 0,680 & 5,88 & 2,460 & 2,630 \\
\hline $\begin{array}{l}\text { Przepuszczalność }[\mathrm{mD}] \text { - pomiary laboratoryjne } \\
\text { Permeability }[\mathrm{mD}] \text { - laboratory measurements } \\
\text { (Areń i in., 1974) }\end{array}$ & 64 & 0,000 & 3,60 & 0,150 & 0,320 \\
\hline $\begin{array}{l}\text { Przepuszczalność }[\mathrm{mD}] \text { - pomiary laboratoryjne } \\
\text { Permeability }[\mathrm{mD}] \text { - laboratory measurements } \\
\text { (INiG-PIB, 2018) }\end{array}$ & 21 & 0,0003 & 0,60 & 0,002 & 0,0025 \\
\hline $\begin{array}{l}\text { Zailenie [\%] - interpretacja geofizyczna } \\
\text { Shaliness [\%] - geophysical interpretation } \\
\text { (INiG-PIB, 2018) }\end{array}$ & - & 1,190 & 65,30 & 21,600 & 25,900 \\
\hline
\end{tabular}

Tab. 7. Parametry petrofizyczne formacji białogórskiej w otworze Darżlubie IG-1

Table 7. Petrophysical parameters of the Białogóra Formation in the Darżlubie IG-1 borehole

\begin{tabular}{|c|c|c|c|c|c|}
\hline \multirow{2}{*}{$\begin{array}{l}\text { Parametry petrofizyczne } \\
\text { Petrophysical parameters }\end{array}$} & \multicolumn{5}{|c|}{$\begin{array}{l}\text { Formacja bialogórska } \\
\text { Bialogóra Formation }\end{array}$} \\
\hline & $\begin{array}{l}\text { Liczba próbek } \\
\text { Number } \\
\text { of samples }\end{array}$ & Min. & Max. & $\begin{array}{l}\text { Mediana } \\
\text { Median }\end{array}$ & $\begin{array}{l}\text { Średnia } \\
\text { Average }\end{array}$ \\
\hline $\begin{array}{l}\text { Porowatość efektywna [\%] - interpretacja geofizyczna } \\
\text { Effective porosity [\%] - geophysical interpretation } \\
\text { (INiG-PIB, 2018) }\end{array}$ & - & 0,0 & 0,30 & 0,00 & 0,04 \\
\hline $\begin{array}{l}\text { Porowatość efektywna [\%] - pomiary laboratoryjne } \\
\text { Effective porosity [\%] - laboratory measurements } \\
\text { (Areń i in., 1974) }\end{array}$ & 4 & 0,7 & 2,65 & 1,42 & 1,55 \\
\hline $\begin{array}{l}\text { Przepuszczalność }[\mathrm{mD}] \text { - pomiary laboratoryjne } \\
\text { Permeability }[\mathrm{mD}] \text { - laboratory measurements } \\
\text { (Areń i in., 1974) }\end{array}$ & 3 & 0,5 & 0,65 & 0,50 & 0,55 \\
\hline $\begin{array}{l}\text { Zailenie [\%] - interpretacja geofizyczna } \\
\text { Shaliness [\%] - geophysical interpretation } \\
\text { (INiG-PIB, 2018) }\end{array}$ & - & 58,7 & 68,70 & 61,20 & 62,50 \\
\hline
\end{tabular}




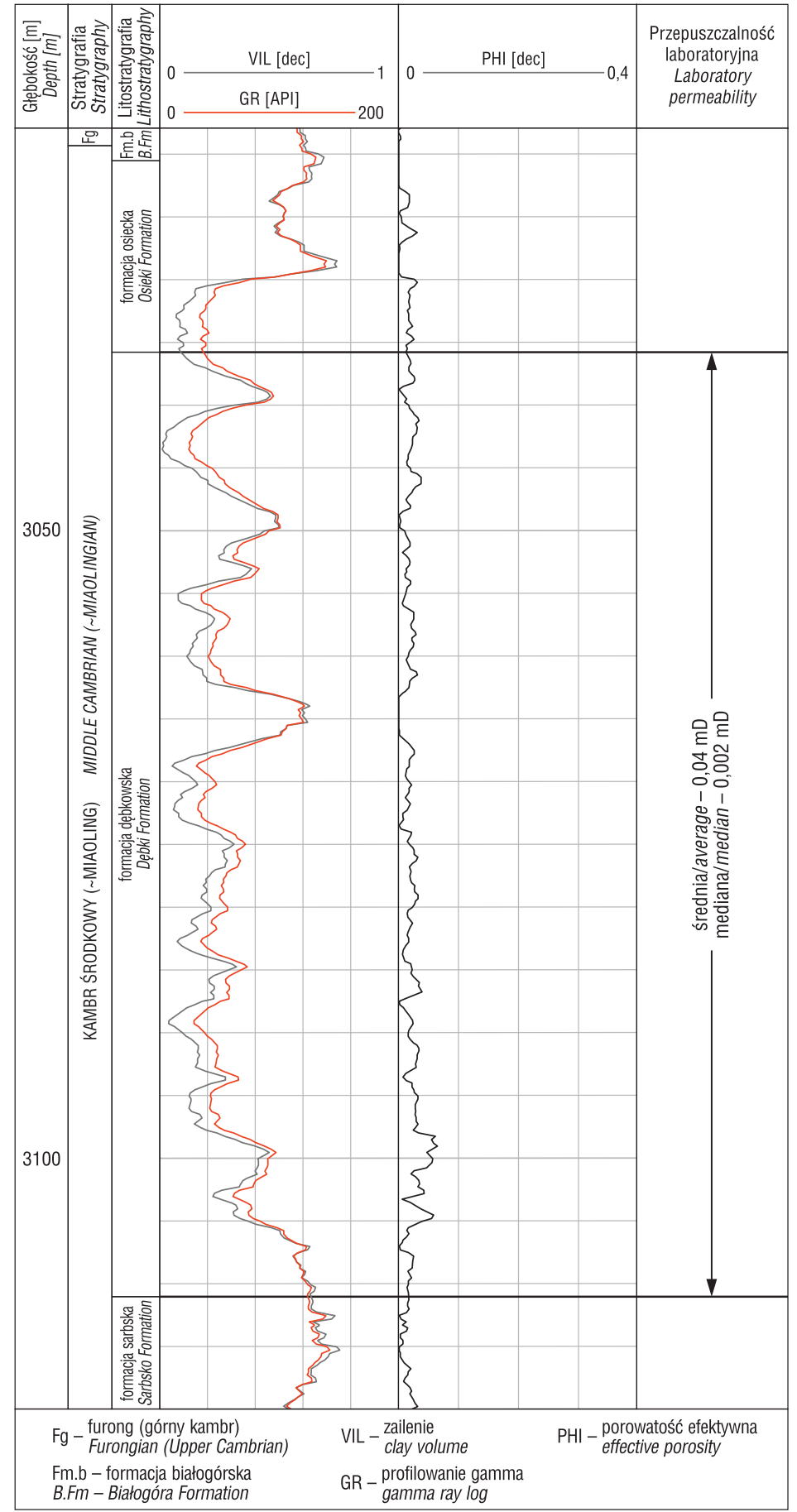

Ryc. 3. Wybrane parametry petrofizyczne charakteryzujące utwory środkowego kambru w otworze Darżlubie IG-1 (według INiG-PIB, 2018)

Fig. 3. Selected petrophysical parameters characteristic for the Middle Cambrian deposits in the Darżlubie IG-1 borehole (after INiG-PIB, 2018)

(tab. 6 i 7), pozwalają rozważać możliwy potencjał tej formacji do nagromadzeń gazu typu tight.

Miąższość formacji białogórskiej, leżącej wyżej w profilu kambru środkowego, wynosi ok. 2,5 m. Parametry petrofizyczne skał tej formacji nie wskazują na jej perspektywiczność.

\section{PODSUMOWANIE}

Liczne objawy obecności węglowodorów w płuczce oraz w rdzeniach wiertniczych pochodzących z utworów środkowego kambru wyniesienia Łeby wskazują, że zarówno na obszarze lądowym, jak i morskim tego wyniesienia obok konwencjonalnych złóż węglowodorów mogą występować nagromadzenia gazu zamkniętego.

Ropogazonośne utwory środkowego kambru są reprezentowane przez formację dębkowską i białogórską. Formacja dębkowska składa się ze zwięzłych, drobnoziarnistych piaskowców kwarcowych. W profilach wszystkich otworów wiertniczych na wyniesieniu Łeby tworzą one monolityczny kompleks skalny o miąższości nie przekraczającej 100 m. Formacja białogórska, do której należą zwięzłe piaskowce drobno- i średnioziarniste, osiąga miąższość od 2 do $10 \mathrm{~m}$, a jej zasięg jest ograniczony regionalnie.

Parametry petrofizyczne piaskowców formacji dębkowskiej i formacji białogórskiej (porowatość całkowita, porowatość efektywna i przepuszczalność pozioma) wskazują, że w profilach 4 analizowanych otworów wiertniczych na wyniesieniu Łeby potencjalne nasycenie gazem zamkniętym nie obejmuje całego interwału głębokościowego tych wydzieleń. Ze względu na warstwowe zróżnicowanie parametrów petrofizycznych badanych formacji skalnych celowe jest dążenie do bardziej precyzyjnego wskazania warstw zwięzłych piaskowców środkowokambryjskich spełniających kryteria złożowe definiujące skały o potencjale do akumulacji gazu zamkniętego.

Wyniki dotychczasowych analiz petrofizycznych oraz uwarunkowania regionalne i geologiczne świadczą o nierównomiernym rozłożeniu właściwości zbiornikowych istotnych dla możliwości występowania gazu zamkniętego w utworach środkowego kambru wyniesienia Łeby, w obu analizowanych formacjach. Większym potencjałem występowania nagromadzeń gazu zamkniętego cechuje się formacja dębkowska.

Przedstawiona w niniejszym artykule wstępna analiza potencjału utworów środkowego kambru zachodniej części obniżenia bałtyckiego do akumulacji gazu zamkniętego wskazuje na potrzebę realizacji w przyszłości badań umożliwiających oszacowanie szerszego zakresu parametrów petrofizycznych. Autorki dostrzegają potrzebę przeprowadzenia pogłębionych badań, w tym określenia nasycenia wytypowanych formacji skalnych wodac złożową, analiz dotyczących ciśnienia złożowego oraz szczegółowej analizy objawów węglowodorów w płuczce i rdzeniu wiertniczym. W celu wyjaśnienia specyfiki zmienności parametrów petrofizycznych badanych formacji skalnych należałoby także podjąć analizy związane $\mathrm{z}$ historią ewolucji przestrzeni porowych, diagenezą cementów, historią termiczną fluidów, kompakcją i dekompakcją piaskowców kambryjskich.

Autorki pragną serdecznie podziękować Recenzentom artykułu Pani prof. Jadwidze Jarzynie i Panu dr. Hubertowi Kiersnowskiemu za cenne uwagi, które merytorycznie wzbogaciły artykuł. Badania zostały sfinansowane przez Narodowy Fundusz Ochrony Środowiska i Gospodarki Wodnej w ramach zadania 22.5004.1502.03.0. Rozpoznanie stref perspektywicznych dla występowania niekonwencjonalnych złóż węglowodorów w Polsce, realizowanego w Państwowym Instytucie Geologicznym Państwowym Instytucie Badawczym w latach 2016-2018. 


\section{LITERATURA}

AREŃ B., BOJARSKI L., DAYCZAK-CALIKOWSKA K., DEMBOWSKA J., JASKOWIAK-SCHOENEICHOWA M., LENDZION K., MODLIŃSKI Z., RYKA W., SZYPERKO-ŚLIWCZYŃSKA A., TOMCZYK H., WAGNER R. 1974 - Dokumentacja wynikowa otworu badawczego (parametryczno-strukturalnego) Darżlubie IG-1.CAG PIG, Warszawa, nr inw. 118175.

DADLEZ R. 1993 - Pre-Cenozoic tectonic of the southern Baltic Sea. Geol. Quart., 37: 431-450.

GÓRECKI W. 2006 - Zbiornik hydrogeotermalny kambru. [W:] Atlas Zasobów Geotermalnych Formacji Paleozoicznej na Niżu Polskim. Min Środowiska, Narodowy Fundusz Ochrony Środowiska i Gospodark Wodnej, AGH, Zakład Surowców Energetycznych AGH, Państw. Inst. Geol.: 216-219

GÓRECKI W. 2011 - Formacja ropogazonośna kambru na platformie wschodnioeuropejskiej. [W:] Wołkowicz S., Smakowski T., Speczik S. (red.), Bilans perspektywicznych zasobów kopalin Polski wg stanu na 31.XII.2009 r. Państw. Inst. Geol. - PIB: 29-30.

INiG-PIB 2018 - Ocena perspektywiczności kompleksów skalnych na podstawie laboratoryjnych badań petrofizycznych właściwości skał oraz analizy profilowań geofizyki otworowej (określenie TOC oraz petrofizycznych właściwości skał) w 15-20 otworach wiertniczych wraz z interpretacja i naukowym opracowaniem wyników. Etap II, Instytut Nafty I Gazu - Państwowy Instytut Badawczy. [W:] Podhalańska i in. Rozpoznanie stref perspektywicznych dla występowania niekonwencjonalnych złóż węglowodorów w Polsce, stałe zadanie PSG. CAG Państw. Inst. Geol., Warszawa, nr inw. 9051/2019.

JAWOROWSKI K. 2000 - Facies variability in the Cambrian deposits from the Kościerzyna and Gdańsk sections (Pomeranian Caledonides foreland, northern Poland): a comparative study. Geol. Quart., 44 (2) 249-260.

JAWOROWSKI K. 2011- Charakterystyka sedymentologiczna osadów ediakaru i kambru. [W:] Modliński Z. (red.), Darżlubie IG 1. Prof. Głęb. Otw. Wiert. PIG, 128: 68-75.

KARCZEWSKA A., ŻURAWSKI E. 1998 - Złoża obszaru morskiego. [W:] Modliński i in., Ocena perspektyw poszukiwawczych złóż ropy naftowej i gazu ziemnego w utworach kambru syneklizy bałtyckiej na podstawie analizy basenów sedymentacyjnych starszego paleozoiku. CAG Państw. Inst. Geol., Warszawa, nr inw. 2903/98

KOEHRER B., WIMMERS K., STROBEL J. 2014 - Understanding Net Pay in Tight Gas Sands - A Case Study from Lower Saxony Basin, NW Germany. $76^{\text {th }}$ EAGE Conference \& Exhibition 2014, Amsterdam RAI, The Netherlands.

KOSAKOWSKI P., WRÓBEL M., POPRAWA P. 2010 - Hydrocarbon generation expulsion modeling of the Lower Palaeozoic source rock in the Polish part of the Baltic Basin. Geol. Quart., 54 (2): 241-256. KOSAKOWSKI P., KOTARBA M., PIESTRZYNSKI A., SHOGENOVA A., WIECCŁAW D. 2016 - Petroleum source rock evaluation of the Alum and Dictyonema Shales (Upper Cambrian - Lower Ordovician) in the Baltic Basin and Podlasie Depression (Eastern Poland). Intern. J. Earth Sciences, 106: 743-761.

KRÓLICKA J. 1998 - Złoża obszaru lądowego. [W:] Modliński i in., Ocena perspektyw poszukiwawczych złóż ropy naftowej i gazu ziemnego w utworach kambru syneklizy bałtyckiej na podstawie analizy basenów sedymentacyjnych starszego paleozoiku. CAG Państw. Inst. Geol., Warszawa, nr inw. 2903/98
KUBALA A., SŁABY A., NOCOŃ J., KOCIK G., PIETRZYCKA S., PIETRZYCKI D., ŚLIWINSSKI P., SOBIECH K., DYL K., CYGNAR H. 2015 - Dokumentacja geologiczna wynikowa otworu rozpoznawczego B21-2/2014 obszar morski RP - koncesja Gaz Południe. CAG Państw. Inst. Geol., Warszawa, nr inw. 917/2016, 918/2016 i 919/2016.

LEE E.C. 2013 - Natural fracture analysis related to depositional environment and strain variability in the middle and upper Williams Fork Formation, Piceance Basin, Colorado. M.Sc. thesis. Colorado School of Mines.

LENDZION K. 1983 - Rozwój kambryjskich osadów platformowych Polski. Pr. Inst. Geol., 105: 1-55.

PACZEŚNA J. 2011 - Litologia i stratygrafia kambru. [W:] Modliński Z. (red.), Darżlubie IG 1, Prof. Głęb. Otw. Wiert. PIG, 128, 53-54.

PACZEŚNA J. 2012 - Wysokorozdzielcza stratygrafia sekwencji utworów środkowego kambru w południowej i północno-wschodniej części bloku B (wyniesienie Łeby). Biul. Państw. Inst. Geol., 448: 71-80. PACZEŚNA J., POPRAWA P. 2005 - Eustatic versus tectonic control on the development of Neoproterozoic and Cambrian stratigraphic sequences of the Lublin-Podlasie Basin (SW margin of Baltica). Geosci. J., 9 (2), 117-127.

PODHALAŃSKA T., ADAMCZAK-BIAŁY T., BECKER A., DYRKA I., FELDMAN-OLSZEWSKA A., GŁUSZYŃSKI A., GROTEK I., JANAS M., JARMOŁOWICZ-SZULC K., JACHOWICZ M., KARCZ P., KLIMUSZKO E., KOZŁOWSKA A., KRZYŻAK E., KUBERSKA A., NOWAK G., PACHYTEL R., PACZEŚNA J., ROMAN M., SIKORSKA-JAWOROWSKA M., SKOWROŃSKI L., SOBIEŃ K., TRELA W., TRZEPIERCZYŃSKA A., WAKSMUNDZKA M. I., WOŁKOWICZ K., WÓJCICKI A. 2018 - Rozpoznanie stref perspektywicznych dla występowania niekonwencjonalnych złóż węglowodorów w Polsce, stałe zadanie PSG, II etap, Opracowanie końcowe. NAG Państw. Inst. Geol., Warszawa, nr inw. 9051/2019.

POKORSKI J., MODLIŃSKI Z. 2007 - Mapa geologiczna zachodniej i centralnej części obniżenia bałtyckiego bez utworów permu i młodszych: 1:750 000. Państw. Inst. Geol.

POPRAWA P., PACZEŚNA J. 2002 - Późnoneoproterozoiczny do wczesnopaleozoiczny rozwój ryftu na lubelsko-podlaskim skłonie kratonu wschodnioeuropejskiego - analiza subsydencji i zapisu facjalnego. Prz. Geol. 50: 49-61.

POPRAWA P., GROTEK I. 2005 - Revealing palaeo-heat flow and paleooverpressures in the Baltic Basin from thermal maturity modeling. Mineralogical Soc. of Poland, Sp. Papers, 26: 235-238.

RYKA W. 1990 - Pre-Karelian rocks in Warmia, NE Poland. Arch. Mineral. 46: $32-54$

WÓJCICKI A., KIERSNOWSKI H., DYRKA I., ADAMCZAK-BIAŁY T., BECKER A., GŁUSZYŃSKI A., JANAS M., KOZŁOWSKA A., KRZEMIŃSKI L., KUBERSKA M., PACZEŚNA J., PODHALAŃSKA T., ROMAN M., SKOWRONSKI L., WAKSMUNDZKA M.I. 2014 Prognostyczne zasoby gazu ziemnego w wybranych zwięzłych skałach zbiornikowych Polski (raport wykonany w ramach tematu PSG realizowanego na zamówienie MŚ i za środki NFOŚiGW, dostępny na stronie PIG-PIB). Państw. Inst. Geol.-PIB, Warszawa.

WRÓBLEWSKI J. 2012 - Raport końcowy z prac geologicznych na obszarze koncesyjnym „Stupsk” przeprowadzonych w roku 2011 przez Saponis Investments Sp. z o.o. CAG Państw. Inst. Geol., Warszawa, nr inw. 2980/2017.

Praca wpłynęła do redakcji 7.02.2020 r. Akceptowano do druku 3.07.2020 r. 